\title{
PALAEOENVIRONMENTAL SIGNIFICANCE OF A LATE MIOCENE BENTHIC FORAMINIFERA FAUNA FROM APOSTOLI FORMATION, CENTRAL WEST CRETE, GREECE

\author{
H. DRINIA ${ }^{1}$
}

\begin{abstract}
The palaeoenvironmental and palaeoecological reconstruction of the Apostoli Basin (Crete, Rethymnon Region) during early Late Miocene by means of benthic foraminifers is given. Biologically important factors, such as oxygen and nutrient content of sea-water, played a great role in the evolution of the palaeoecosystem. A gradual deepening took place during the deposition of the Apostoli Formation. The sediments of the lower part of the formation document a shallow-marine environment with vegetation in the neighborhood. In the middle part of the formation sediments are characterized by intermediate oxygenated conditions, whereas the upper part of it is characterized by the establishment of a restricted envrironment, where organic matter accumulates and infaunal opportunistic species capable of surviving in stressed conditions dominate, being favoured by abundant nutrients.
\end{abstract}

KEY WORDS: Crete, Late Miocene, Benthic foraminifers, palaeoenvironment.

\section{INTRODUCTION}

The study area forms part of the Apostoli Basin, which is located in the Rethymnon Region in Central West Crete. Meulenkamp (1969) established the geological setting of the basin, while Drinia (1996) revised its stratigraphy. In the meantime, biostratigraphical and stratigraphical research in the broader area of Rethymnon Province has been carried out by many workers (De Bruijn \& Meulenkamp, 1972; Georgiades-Dikeoulia, 1974; Melentis, 1974; Symeonides \& Sondaar, 1975; Meulenkamp, 1979; Georgiades-Dikeoulia, 1979; Frydas, 1989; Frydas \& Keupp, 1992; Keupp \& Kohring, 1999; Drinia et al., 1997; Drinia et al., 1998).

The Neogene succession of the Apostoli Basin includes coarse-grained fluviolacustrine deposits (Pandanassa Formation) and conglomerates with alternations of siliciclastic or carbonate shallow-marine sediments (Apostoli Formation). The marine facies gradually increases in thickness and changes into the overlying bioclastic limestones of the Rethymnon Formation.

The purpose of this paper is to reveal biotic and palaeoenvironmental trends in Apostoli Formation during the early Late Miocene by quantitatively analyzing benthic foraminiferal assemblages.

\section{STUDY AREA}

The studied Apostoli Formation has been sampled in the Apostoli section, which is situated near the village of Apostoli in the province of Rethymnon (Fig. 1).

The Apostoli Formation is mainly constituted by marly-silty sedimentation at the top of the siliciclastic succession of Pandanassa Formation. The transition from fluviolacustrine to marine sedimentation is marked by the appearance of burrowing features and marine fossils such as Heterostegina in conglomeratic-sandy deposits. Upwards the sequence passes into grey, bluish-grey and brownish-grey, silty or sandy clays, which yield a rich mollusc fauna.

The analysis of the deposits of the Apostoli Formation based on calcareous nannofossils (Drinia et al., 1997; 1998) allows the assignment of the formation to CN8a (upper part)/CN9a (top) biozones (Okada \& Bukry, 1980, suggesting a Middle-Upper Tortonian age.

\section{METHODS AND MATERIAL}

In order to obtain insight into general palaeoenvironmental conditions, $\mathrm{P} / \mathrm{B}$ ratios, the diversity of the benthics and the proportion of the most frequent taxon have been calculated. The $\mathrm{P} / \mathrm{B}$ ratio is expressed as a calculation

1. University of Athens, Dept.of Geology, Section of Hist. Geology-Paleontology, Panepistimiopolis, 157 84, Athens Greece. 
of $\mathrm{P} / \mathrm{P}+\mathrm{Bx} 100$ (the percentage of planktonic foraminifers of the total foraminiferal population).
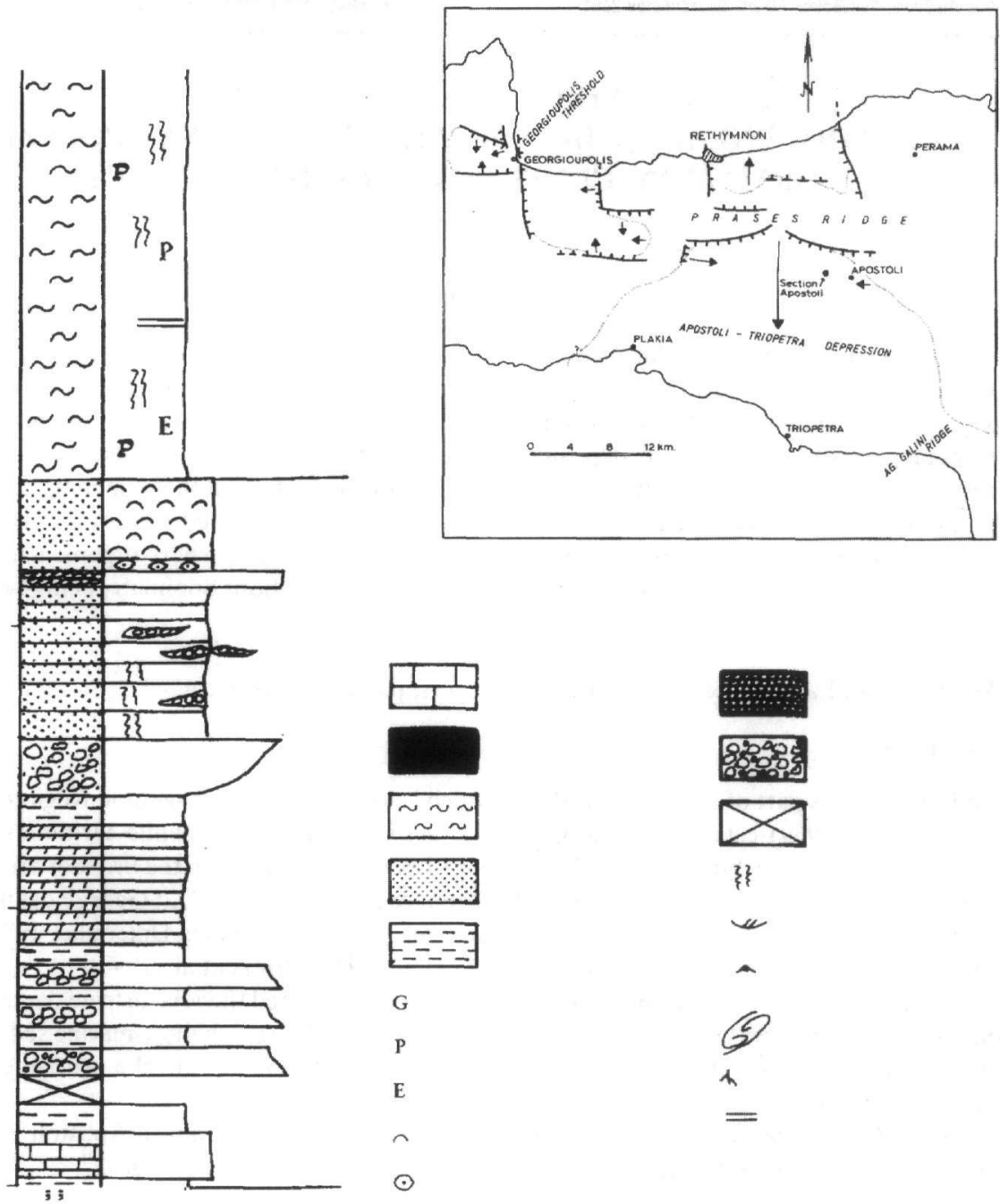

G

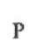

$P$

E

$\xi \xi$
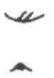

(1)

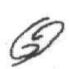

h

$=$

$\odot$

Fig. 1. The Apostoli section, at Apostoli, Province of Rethymnon.

In addition, the general relationship between depth and marine productivity espressed as $\% \mathrm{P}=\mathrm{P} / \mathrm{P}+\mathrm{Bx} 100$ (where $\mathrm{P}$ is for planktonic foraminifers and $\mathrm{B}$ is for benthic foraminifers) is described according to: Depth $=\mathrm{e}^{(3.58718+(0.03534 \% \%)}$ (Zwaan et al., 1990).

The diversity of the species per sample is measured by using the Shannon-Wiever formula (Margalef, 1968)which is:

$$
\begin{gathered}
\mathrm{M}=-\sum \mathrm{p}_{\mathrm{i}} \ln \mathrm{p}_{\mathrm{i}} \\
\mathrm{i}=1
\end{gathered}
$$

where $\mathrm{pi}=\mathrm{ni} / \mathrm{N}$ (ni=the number of individuals of the $\mathrm{i}^{\mathrm{th}}$ species and $\mathrm{N}$ the total number of individuals) and $\mathrm{M}$ is the total number of species. Finally, the index of Evenness $(J)$ is defined by the formula $J=H / H m a x$ (Margalef, 1968) where $\mathrm{H}=$ diversity and $\mathrm{Hmax}=\ln M$.

\section{PALAEOECOlOgical aNALYSIS}

The study of the listed benthic foraminifers allows the following qualitative analysis of Apostoli Formation (Table 1): 
Table 1: List of the determined benthic foraminifera

\begin{tabular}{|c|c|}
\hline Asterigerinata planorbis (D'ORBIGNY) & Gyroidinoides umbonatus (SILVESTRI) \\
\hline Ammonia beccarii (Linnaeus) & Hanzawia boueana (d'Orbigny) \\
\hline Ammonia perlucida (Heron-Allen\&Earland) & Hoeglundina sp. \\
\hline Angulogenerina angulosa (Williamson) & Hoeglundina elegans (d'Orbigny) \\
\hline Astrononion sp. & Lagena sulcata (Walker\&Jacob) \\
\hline Bigenerina sp. & Lenticulina sp. \\
\hline Bolivina antiqua d'orbigny & Melonis pompilioides (Fichtel\&Moll) \\
\hline Bolivina pseudoplicata Heron-Allen\&Earland & Miliolidae \\
\hline Bolivina spathulata (Williamson) & Nodosaria scalaris (Batsch) \\
\hline Balivina tortuosa Brady & Nodosaria sp. \\
\hline Bulimina aculeata (d'orbigny) & Nonion depressulum (Walker\&Jacob) \\
\hline Bulimina costata (d'Orbigny) & Nonion soldanit \\
\hline Bulimina elongata (d'Orbigny) & Nonionella sp. \\
\hline Cancris sp. & Oridorsalis umbonatus (Reuss) \\
\hline Cassidulina sp. & Paracassidulina sagamiensis Assano\&Nacamura \\
\hline Cibicides sp. & Pullenia quinqueloba Reuss \\
\hline Cibicides dutemplei (d'Orbigny) & Reusella spinulosa (Reuss) \\
\hline Cibicides lobatulus (Walker\&Jacob) & Rosalina globularis d'Orbigny \\
\hline Cibicides refulgens Montfort & Siphonina bradyana Cushman \\
\hline Cribrononion gerthi (Cole) & Siphonina reticulata Czizek \\
\hline Cribrononion asklundi (Brotzen) & Spiroplectamina carinata d'orbigny \\
\hline Discorbis spp. & Textularia agglutinans d'Orbigny \\
\hline Elphidium spp. & Textularia candeiana d'orbigny \\
\hline Elphidium crispum (Linnaeus) & Trifarina bradyi (Williamson) \\
\hline Elphidium fichtellianum (d'Orbigny) & Uvigerina bononiensis Fornansini \\
\hline Eponides sp. & Uvigerina cylindrica gaudrynoides d'Orbigny \\
\hline Fissurina orbignyana Sequenza & Uvigerina peregrina Cushman \\
\hline Fissurina bisulcata (Heron-Allen\&Earland) & Uvigerina rutila d'Orbigny \\
\hline Globocassidulina subglobosa (Brady) & Valvulineria bradyana Formasini \\
\hline Gyroidinoides sp. & Valvulineria complanata ( $\mathrm{D}^{\prime}$ Orbigny) \\
\hline Gyroidinoides soldanii (d' Orbigny) & \\
\hline
\end{tabular}

It is known that species fitness is primarily affected by changes in nutrient abundance and to a much lesser extent by factors such as salinity and temperature. Therefore, according to their reactions to environmental changes expressed in terms of food abundance-competition for food and salinity, the benthic foraminifers determined have been grouped in three categories (according to Zwaan, 1982).

Group A: comprises species showing an indifferent reaction to any environmental change, which means that they are greatly tolerant to physical/chemical changes. These species are mostly epiphytes or vegetation bound or show a positive correlation with epiphytes. These are the following: Cibicides lobatulus, C. refulgens, Discorbis spp., Asterigerinata planorbis, Reusella spinulosa, Elphidium spp., Bolivina pseudoplicata, miliolids, Ammonia beccarii, Cibicides sp.

Group B:is composed of species, which inhabit stable marine conditions. They show intolerance to oxygen deficiency as well as increased salinity and never proliferate during times of nutrient abundance. These are usually open marine species, which inhabit a considerable depth range, living mainly on muddy substrates. These species are: Cibicides dutemplei, Hanzawaia boueana, Siphonina bradyana, Gyroidinoides sp., Uvigerina peregrina, $U$. rutila, Nonion soldanii, Melonis pompilioides and agglutinants.

Group C: is represented by species, which tolerate a great deal of environmental change and are tolerant to oxygen deficiency as well as salinity increase. They proliferate during periods of nutrient abundance (stressed and nutrient-rich environments). These are: Bolivina spathulata, Bulimina aculeata, B. elongata, B. costata, Cassidulina sp., Valvulineria complanata, Uvigerina cylindrica gaudrynoides.

In addition, frequency curves have been created for the following species of group of species:

Uvigerina peregrina Group,(including U. peregrina, U. bononiensis, U. cylindrica gaudrynoides, U. rutila),.Bolivina spathulata Group (Bolivina spathulata, B. antiqua, B. tortuosa and Bulimina aculeata, B. elongata, B. costata),.Gyroidinoides soldanii Group (G. soldanii, G. umbonatus, Gyroidinoides sp. as well as Hoeglundina elegans, Melonis pompilioides, Pullenia quinqueloba, Nonion sp), Cibicides lobatulus Group (C. lobatulus, C. refulgens, $C$. lobatulus trans type refulgens, Cibicides sp.), Group of miliolids and Group of agglutinants. 
From the quantitative data (Table 2) and the plotted diagrams (Fig. 2) have been concluded:

\begin{tabular}{||l|c|c|c|c|c|c|c|c||}
\hline \multicolumn{1}{|c|}{ SAMPLES } & AP1 & AP2 & AP3 & AP4 & AP5 & AP6 & AP7 & AP8 \\
\hline Benthic Forams & 165 & 229 & 138 & 223 & 196 & 330 & 288 & 249 \\
\hline Plankton ic Forams & 36 & 102 & 71 & 104 & 100 & 435 & 216 & 368 \\
\hline Group A & 63,9 & 45,8 & 20,5 & 28,1 & 28,4 & 28,3 & 48,1 & 27,7 \\
\hline Group B & 17,4 & 39,7 & 51 & 40,2 & 42,2 & 40 & 22,1 & 20 \\
\hline Group C & 8,7 & 2,3 & 4,6 & 3,6 & 4,2 & 18 & 8,8 & 41,8 \\
\hline C. lobatulus group & 23,9 & 18,3 & 6,5 & 19 & 17,6 & 12 & 17,5 & 5 \\
\hline C. dutemplei group & 4,3 & 9,2 & 7,4 & 4,1 & 4,2 & 16,7 & 3,7 & 2,5 \\
\hline B. spathulata group & 7,6 & 4,6 & 4,6 & 3,6 & 8,4 & 21,6 & 10,9 & 41,4 \\
\hline G. soldanii group & 2,2 & 13 & 8,3 & 12,9 & 7,8 & 5,9 & 9,6 & 5 \\
\hline U. peregrina group & 0 & 6,8 & 1 & 11,3 & 20,4 & 3,8 & 4,6 & 13,1 \\
\hline Agglu tin ants & 0 & 7,6 & 27,7 & 8,2 & 8,4 & 2,7 & 5,8 & 0 \\
\hline Miliolidae & 1,1 & 10 & 8,3 & 6,7 & 8,4 & 1,1 & 0 \\
\hline Diversity (H) & 2,22 & 1,8 & 2,31 & 2,28 & 2,28 & 1,2 & 2,5 \\
\hline Evenness (J) & 0,89 & 0,62 & 0,93 & 0,89 & 0,89 & 0,4 & 0,92 & 0,89 \\
\hline P/ P+B & 0,18 & 0,31 & 0,34 & 0,32 & 0,34 & 0,57 & 0,43 & 0,6 \\
\hline Depth (m) & 68,04 & 107,3 & 120,0 & 111,1 & 119,2 & 269,5 & 164,3 & 297,4 \\
\hline
\end{tabular}

The $\mathrm{P} / \mathrm{B}+\mathrm{P}$ ratio varies between 0.18 and 0.6 . Relatively high values are confined to samples of the upper part of the Formation (Fig. 3a). The depth of deposition as has been reconstructed using the relevant formula ranges from 68.04 to $297.37 \mathrm{~m}$ wd (Fig. 3b) indicating the transition from middle neritic to the upper bathyal zone.

As far as the diversity and evenness indices are concerned (Fig. 4a, b), these remain constant with smallscale changes. Shannon diversity $(\mathrm{H})$ values generally fluctuate between 1.2 to 2.5 . Highest diversity is reached at sample AP7. The Evenness Index (J) remains constant for the eight samples ranging from 0.4 to 0.93 indicating a trend for predominance of a single species.

From the frequency diagrams (Fig. 2) it may be inferred that the entire section sampled is characterized by high percentage values of the representatives of the Group A and Group B.

The first three samples (AP1-AP3) of the section are characterized by a decline in the abundance of Group A and an increase of Group B. These three samples contain a rather rich and diversified benthic fauna, which points to a stable marine environment. Between the deposition of the layers corresponding to the samples AP1 and AP3, an important event must have taken place: the character of the faunal associations changes from shallow marine to deeper marine, indicating the establishment of stable conditions. In particular, the increase of Group B in sample AP3 may be due to the abrupt increase of the representatives of the agglutinated Group. According to Kaminski et al. (1995), the prevalence of agglutinants indicates intermediate oxygenated conditions. Additionally, the same sample is characterized by rather low values of the $\mathrm{P} / \mathrm{B}$ ratio. This low $\mathrm{P} / \mathrm{B}$ ratio is generally associated with shallow water or restricted environments, but may also result from calcite dissolution, because planktonic foraminifers are generally more susceptible to dissolution than most of the benthics (Murray, 1991). Nini (1996) claims that the low $P / B$ ratio and the high number of agglutinated tests could represent two different responses to the same environmental variation: partial dissolution of the planktonic tests or development of a primary agglutinated dominated fauna, better adapted to sea bottom conditions.

In sample AP4 an improvement in bottom conditions is indicated by the increase of Cibicides species, whereas in sample AP5, the abundance of Gyroidinoides and Uvigerina species indicates that oxygen and relatively few nutrients were available at the bottom. Sample AP6 show decreasing diversity, while the composition of the benthic association indicates that the nutrient level was considerably lowered. This low diversity indicates rather restricted bottom life (high levels of environmental stress at the sea-floor). Oxygen deficiency is an important component of this ecological stress.

In the case of AP7 sample, bottom conditions were slightly more favourable as this is indicated by the higher percentage values of group A and group B. The small percentage of the Bolivina spathulata group and the increase in percentage values of the Cibicides lobatulus group and Gyroidinoides soldanii group also support this fact. The high percentage of Group A of epiphytic species may indicate the proximity of vegetated areas. It should be borne in mind that this entire group might represent an allochthonous constituent of the assemblage. 

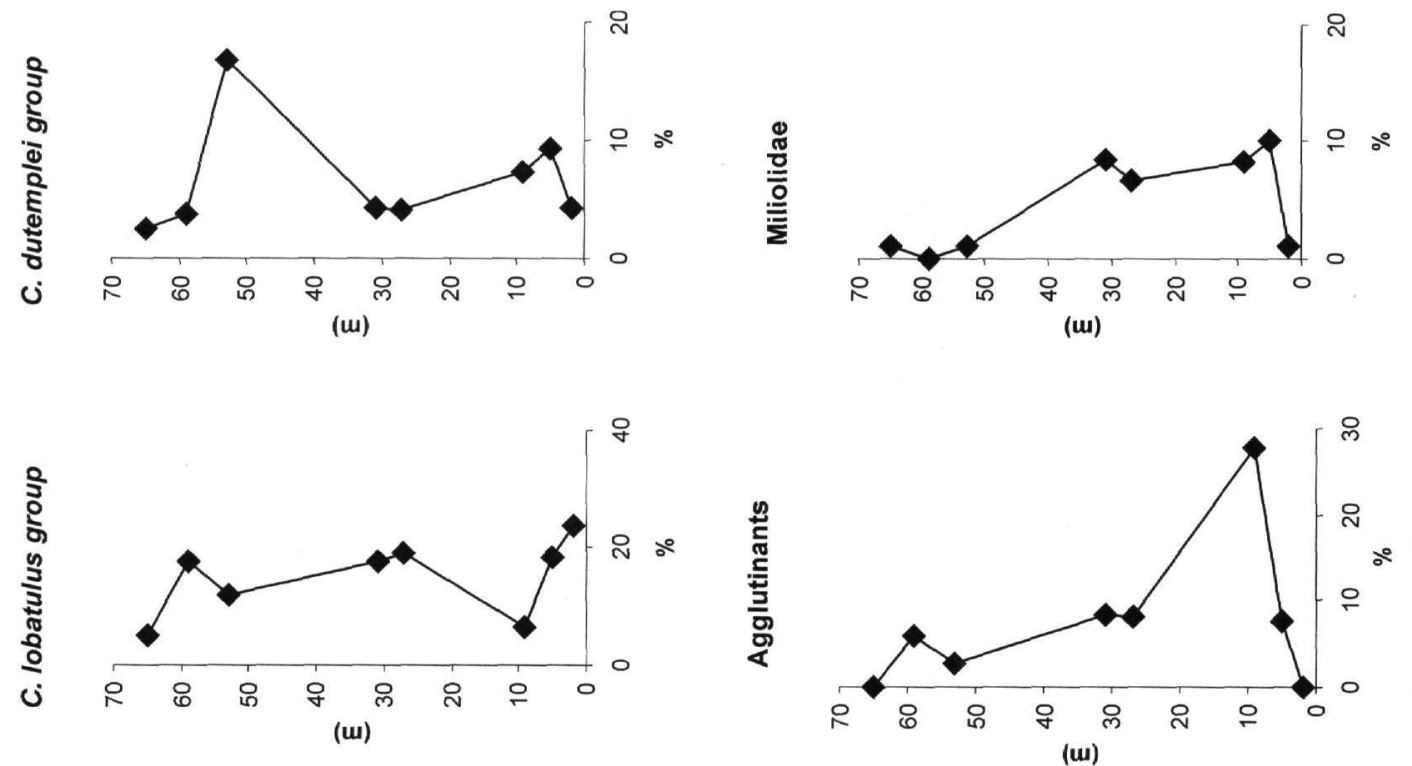

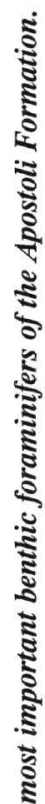
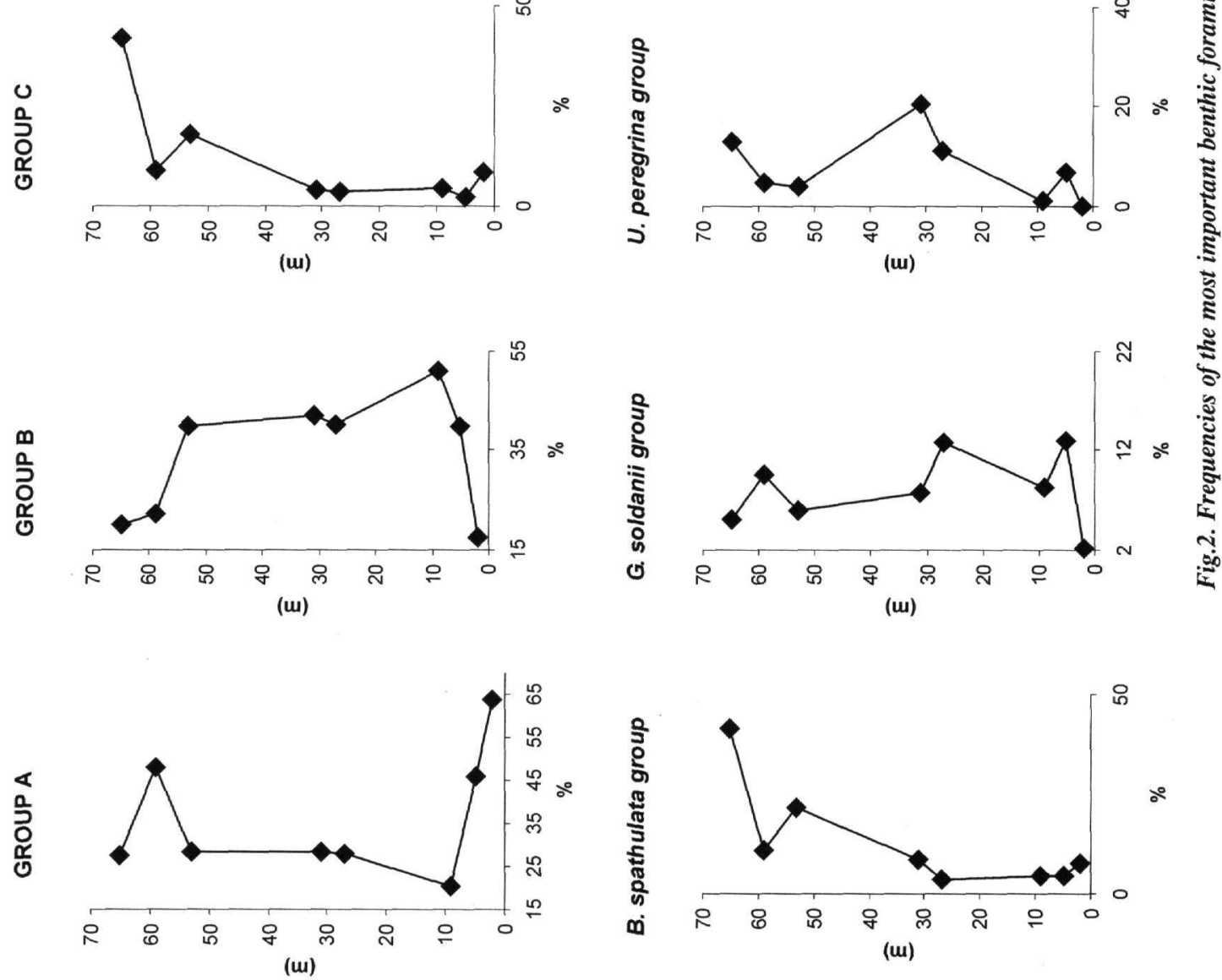

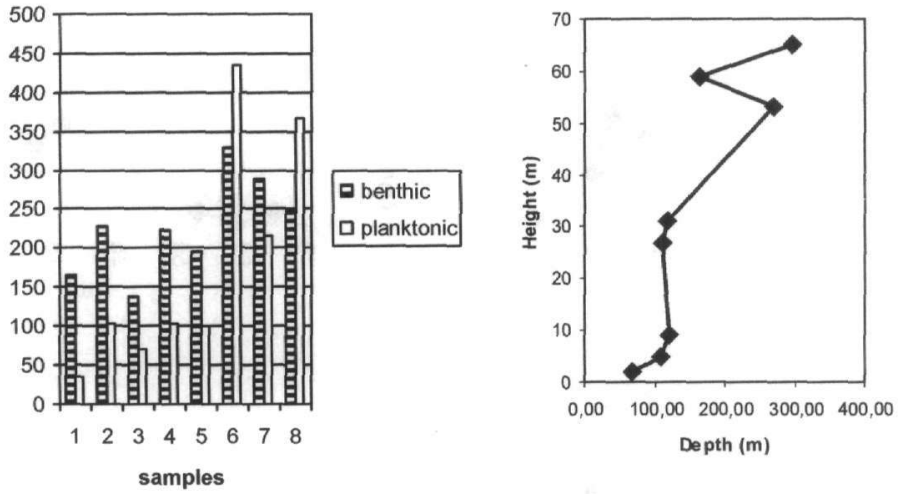

Fig. 3a. Benthic and Planktonic Foraminifera distribution of the studied samples. 3b. Water depth distribution of the studied samples.

Diversity (H)

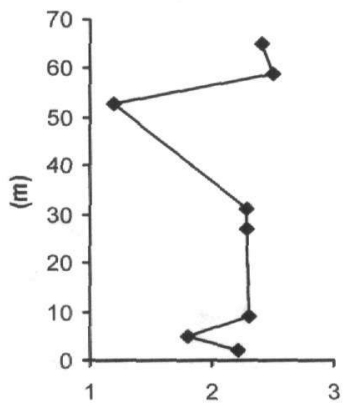

(H)
Evenness

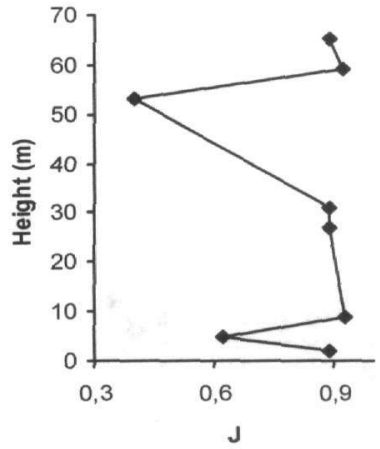

Fig. 4a,b.Diversity (H) and Evenness (J) indices in the studied samples.

The higher diversity of the sample corresponds to low levels of ecological stress, as commonly met in relatively stable and well-ventilated deep-sea environment (e.g. Boltovskoy \& Wright, 1976; Murray, 1991).

Environmental conditions must have changed considerably during the deposition of the sample AP8. The conditions that led to the high numbers of representatives of Group $\mathrm{C}$ are not well understood. It is possible that an increase of the salinity played a role in the seas at the time. Representatives of this group are the least sensitive to hypoxia and therefore are typical for low oxygen environment. Moreover, the strong appearance of the Bolivina spathulata group suggests enhanced food levels, lowered oxygenation or a combination of these interrelated parameters (e.g. Corliss \& Chen, 1988; Sen Gupta \& Machain-Castillo, 1993). The reappearance of Uvigerina peregrina further supports that oxygen contents may be a controlling factor in its distribution. In addition, Seiglie (1968) U. peregrina to be correlated with sediments rich in organic matter.

\section{CONCLUSIONS}

A palaeoenvironmental and palaeoecological reconstruction of the Apostoli Basin during the early Late Miocene is suggested.

A gradual deepening took place during the deposition of the Apostoli Formation. Three critical episodes for the benthic foraminiferal fauna occur in the lower, lower-middle and upper part of the formation.

The lower part of the formation corresponds to a rather shallow marine environment with vegetation in the neighbourhood; epiphytes are mixed with a mud-dwelling association.

In the lower to middle part of the formation the character of the faunal associations changes. The develop- 
ment of the representatives of Group B may be related to intermediate oxygenated conditions.

In the upper part of the formation, Group $\mathrm{C}$ represents the establishment of a restricted environment with abundant nutrients; where organic matter accumulates and infaunal opportunistic species capable of surviving in stressed conditions dominate.

The abrupt reappearance of representative species of Group A in this part of the formation may suggest that these shallow living species were all transported in a distal direction by plant-rafting and should therefore be considered as allochthonous in deeper mud environments.

The data indicate that biologically important factors such as oxygen and nutrient content of the waters played a great role in the palaeoecosystem evolution.

The benthic association up to sample AP6 points to ample nutrients and oxygen at the bottom. From sample AP6 onwards the faunal pattern points to a decreasing supply of nutrients and/or oxygen. Probably vertical circulation slowed down, owing to the increased surface temperature.

\section{REFERENCES}

BOLTOVSKOY, E. \& WRIGHT, R. 1976. Recent Foraminifers. Dr. W. Junk, the Hague, 515 pp.

BOLTOVSKOY, E. \& TOTAH, V. 1985. Diversity, similarity and dominance in benthic foraminifersl fauna along one transect of the Argentine shelf. Revue de Micropaleontologie, 1(28), 23-31.

CORLISS, B.H. \& CHEN, C. 1988. Morphotype patterns of Norwegian Sea deep-sea benthic foraminifers and ecological implications. Geology, 16, 716-719.

DE BRUJIN, H. \& J.E. MEULENKAMP, 1972. Late Miocene rodents from the Pandanassa Formation (prov. Rethymnon), Crete, Greece. Proc. Koninklijke nederlanden Akademie van Wetenschappen, 75, 54-60.

DERMITZAKIS, M.D., 1978. Stratigraphy and sedimentary history of the Miocene of Zakynthos island. Annales Geologiques des Pays Helleniques, 29, 47-186.

DRINIA, H., 1996. Late Cenozoic clastic sedimentation in West Crete - Apostoli Basin (Rethymnon Province). PhD Thesis, University of Athens, 187p., Athens.

DRINIA, H., TRIANTAPHYLLOU, M.V. \& DERMITZAKIS, M.D. 1997. Cyclic sedimentation and biostratigraphic-paleoecological analysis of the marine sediments of Potami section (Apostoli Basin-Rethymnon Province, Crete). Proceedings of the $5^{\text {th }}$ Hellenic Symposium of Oceanography and Fishery, vol. 1, 419-422.

DRINIA, H., TRIANTAPHYLLOU, M.V. \& DERMITZAKIS, M.D. 1998. Sedimentary facies analysis and biostratigraphical implications of the fluvio-marine sediments of central-west Crete. R.C.M.N.S. Congress, May 27-29, 1998, Patras, Coll. Abstr., p. 26.

DROOGER, C.W. \& KAASSCHIETER, J.P.H. 1958. Foraminifers of the Orinoco-Trinidad-Paria Shelf. Rep. Orinoco Shelf Exp., Verh. Kon. Ned. Akad. Wet., afd. nat., ser. 1, vol. 22, 108pp.

FRYDAS, D. \& H. KEUPP, 1992. Kieseliges und Kalkiges Phytoplankton aus dem Neogen von NW - und W Kreta/Griechenland. Berlin geowiss. Abh., E3 :97-111, Berlin.

KEUPP, H. \& R. KOHRING, 1999. Kalkige Dinoflagellaten-Zysten aus dem Ober-Miozan (NN11) W von Rethymnon (Kreta). Berlin geowiss. Abh., E30: 33-53.

FRYDAS, D. \& H. KEUPP, 2000. Biostratigraphical and paleontological research of Lower Pliocene diatoms and silicoglagellates from northwestern Crete, Greece. Berlin geowiss. Abh., E34.

GEORGIADES-DIKEOULIA, E. 1974. Les brachiopodes du Miocene moyen de l' ile de Crete (Aghii Assomati, Rethymnon). Annales geologiques des Pays helleniques, Athens, tome hors serie, fasc. I, 449-455.

KAMINSKI, M.A., BOERSMA, A.,TYSZKA, J. \& HOLBOURN, A.E.L. 1995. Response of deep-water agglutinated foraminifera to dysoxic conditions in the California Borderland basins. In: M.A. Kaminski et al. (Eds). Proceedings of the Fourth International Workshop on Agglutinated Foraminifera. Krakow Poland. Grzybowski Foundation Special Publication, 3, 131-140.

MARGALEF, R. 1968. Perspectives in Ecological Theory. Chicago. University of Chicago Press, 111p.

MARTINI, E. 1971. Standard Tertiary and Quaternary calcareous nannoplankton zonation. In: Farinacci, A. (Ed.) Proc. II Plankt. Conf. Roma, 1970: Roma (Technoscienz), 2, 738-785.

MELENTIS, J.K., 1974.Palaontologische Ausgrabungen in den Hohlen des Gebietes von Rethymnon, Kreta. SciAnnSciFacUn Thess, 14, 17-24.

MEULENKAMP, J.E. 1969. Stratigraphy of Neogene deposits in the Rethymnon province, Crete, with special reference to the phylogeny of uniserial Uvigerina from the Mediterranean Region. Utrecht micropaleontological bull., 2, 168p.

MEULENKAMP, J.E., 1979. Lithostratigraphy and relative chronostratigraphic position of the section Apostoli and Potamidha 1 and 2. Utrecht micropaleontological bull., 21. 
MURRAY, J.W. 1991. Ecology and Palaeoecology of Benthic Foraminifers. Elsevier, Amsterdam, 397pp.

NINI, C. 1996. Benthic foraminiferal assemblages as indicators of restricted conditions in the Lower Miocene (Aquitanian) of the Eastern Tuscany Basin, Lonnano (Arezzo) section. Palaeopelagos, 6, 311-327.

OKADA, H. \& BUKRY, D. 1980. Supplementary modification and introduction of code numbers to the low latitude coccolith biostratigraphic zonation. Marine micropaleontology, 5, 321-325.

SEIGLE, G.A. 1968. Foraminifersl assemblages as indicators of high organic carbon content in sedimentsand of polluted waters. American Association of Petroleum Geology Bulletin, 52, 2231-2241.

SEN GUPTA, B.K. \& MACHAIN-CASTILLO, M.L. 1993. Benthic foraminifers in oxygen-poor habitats. In: Langer, M.R. (Ed.), Foraminiferal Microhabitats. Marine Micropaleontology, 20, 183-201.

SYMEONIDIS, N.K. 1969. Das Miozan in Bereich von Boliones (Landkreis Rethymnon-W. Kreta). Annales geologiques des Pays helleniques, Athens, ser. 1, t. XXI, 30-34.

SYMEONIDIS, N. \& P.Y. SONDAAR, 1975. A new otter from the Pleistocene of Crete. Ann. Geol. Pays Hellen., XXVII, 11-24.

THOMAS, E. 1986. Changes in composition of Neogene benthic foraminifersl faunas in equatorial Pacific and north Atlantic. Palaeogeography, Palaeoclimatology, Palaeoecology, 53, 47-61.

VAN MORKHOVEN, F.P.C.M., W.A. BERGGREN \& EDWARDS, A.S. 1986. Cenozoic Cosmopolitan DeepWater Benthic Foraminifers. Bull. Cent. Rech. Explor. Prod., Elf-Aquitaine, Mem. 11, 421pp.

VERHALLEN, P.J.J.M. 1991. Late Pliocene to Early Pleistocene mediterranean mud-dwelling foraminifers influence of a changing environment on community structure and evolution. Utrecht Micropaleontological Bulletin, Utrecht, 40, 1-219.

ZWAAN V.D., G.J. 1982. Paleoecology of Late Miocene Mediterranean Foraminifers. Utrecht Micropaleontological Bulletin, 25, Utrecht.

ZWAAN V.D., G.J., JORISSEN, F.J. \& DE STIGTER, H.C. 1990. The depth dependency of planktonic/benthic foraminifersl ratios: Constraints and applications. Marine Geology, 95, 1-16. 